\title{
Research on the Integration of Production and Education with China's Occupation Education
}

\author{
Ye Qian \\ School of Finance, Jilin Business and Technology College, Changchun, Jilin Province, China
}

\begin{abstract}
In order to adapt to the new situation of China's vocational education reform, explore the talent training strategy based on the integration of production and education, and cultivate high-quality skilled talents to adapt to the new era, schools must change their thinking as soon as possible, through the measures of industry education integration and collaborative education, with the help of enterprise's teachers and strength, jointly cultivate applied talents meeting the needs of enterprises.
\end{abstract}

Keywords: Integration of Production and Education; Curriculum Construction; Dynamic Mechanism

After years of practice and reform, Jilin Province has explored a variety of representative cooperation modes according to the regional characteristics and cooperation experience. Only $28.6 \%$ of the participating enterprises in the province actively contacted the cooperative colleges and universities, $61.9 \%$ of the enterprises actively contacted by the colleges and universities. Generally speaking, there are several modes as follows:

\section{1. "Co construction of practice base" mode}

The practice base provides students with advanced equipment, technology, training and management, which can effectively make up for the lack of school education and teaching, and create a real environment for practical operation and ability training to improve students' practical work ability. The joint construction of internship base between enterprises and higher vocational colleges can give full play to the advantages of enterprises in the process of training skilled talents, give students the conditions to perceive the actual situation of enterprises in advance, move the classroom to the workshop, students learn by doing, and have the opportunity of excellent and advanced enterprises after graduation, so that enterprises can reduce the training cost in talent recruitment, so as to make up for the funds for building the practice base.

Case: an accounting firm and an institution jointly build an internship base for audit major. The main forms are as follows:

(1) The practice base site and facilities are provided by colleges and universities, with an area of about 100 square meters. The infrastructure includes broadband network and office equipment;

(2) The accounting firm provides senior audit practitioners to enter the practice base to train interns in accounting processing operation; the accounting firm is responsible for the teaching tasks of students in the practice stage;

(3) The firm and the University jointly prepare the internship syllabus, arrange the internship content, student management and teaching assessment; the firm has the right to carry out staff training in the practice base, and has the right to employ college students on a selective basis.

\section{2. "Order mode"}

"Order type" mode refers to the directional talent training mode in which enterprises sign contracts with higher vocational colleges according to the development needs and jointly formulate training standards, order quantity and contract period. Colleges and universities cultivate talents required by enterprises according to cooperation agreements. Under the mode, students also sign directional employment contracts, and enterprises bear part of the education expenses in the learning process. Under this mode, the enterprise predicts the future demand of talents according to the development of the industry, sets up majors, arranges courses and organizes teaching together with the training party (College), and finally arranges the students' directional employment according to the agreement. Both of them play an important role in the process of training practitioners in the future.

Case: a bank, a science and Technology Co., Ltd. and other well-known enterprises have carried out deep cooperation with a college, set up order type training of "title class" in relevant majors, successively set up characteristic teaching classes, selected and trained thousands of students, and delivered a large number of excellent skilled talents to relevant majors, which also ensured the high employment rate of various majors. The order type training mode named by enterprises promotes the transformation of 
the concept and mode of enterprises' real participation in talent training.

\section{3. "Modern apprenticeship" mode}

"Modern apprenticeship" is a training mode with a long history in European and American vocational education, and it is an important way to solve the youth employment problem in such countries. The first mock exam system is a breakthrough and innovation in the school enterprise cooperation in Higher Vocational Colleges in recent years. The mode is based on the training objectives of occupation colleges and related enterprises, arranging students to enter the front-line job learning of the enterprise, relying on the practice instruction of the teachers in Vocational Colleges and the practical guidance of the technicians, and cultivating the real working ability of the interns.

Case: a software technology Co., Ltd. has carried out a "modern apprenticeship" project with e-commerce, network marketing, computer and other majors of a college. In order to improve the quality of professional personnel training and innovate the mode of school enterprise cooperation, the greatest advantage of which is that enterprise engineers act as enterprise mentors. For example, engineers of a technology limited company participate in the modern apprenticeship system and act as enterprise mentors. The students under the guidance are mainly the graduating students of the third grade of higher vocational education. Within three months of cooperation, the college carries out mid-term inspection and final assessment on the students, and the students record their daily learning status in the form of work logs.

\section{4. "Enterprise workstation" mode}

In recent years, under the spirit of the documents issued by the Ministry of education and the Ministry of finance, the training program of engineering professionals has been constantly reformed. On the one hand, in order to make sure that teachers design teaching based on practical work, on the other hand, in order to highlight the cultivation of students' comprehensive professional quality, enterprises and colleges participate in the research and development of technology and products, and many enterprises create "workstations" "There are "tutor workstation" and "student workstation" to realize the integration of enterprises and colleges, the integration of training and theory.

Case: a machinery company and a college "marriage", in the enterprise set up "many professional teachers to work formally in the station, to provide technical solutions for the enterprise's problems, and strengthen the exchange of teachers' workstation in Colleges and universities' professional tutors and enterprise engineers in the station". On the one hand, college teaching, technical guidance and staff training participate in the research of related projects; on the other hand, the enterprise's advantageous equipment and specialty. The environment creates practical posts for teachers and creates opportunities for teachers' professional research and professional title evaluation. "Student workstation" is similar to "practice base", which presents a real professional environment and is suitable for students to carry out comprehensive professional training. Some enterprise workstations have the function of skill certificate training. It has various functions and complementary advantages.

\section{5. "Combination of production, teaching and research"}

The combination of production, teaching and research refers to the coordination of "research, development and production" formed by enterprises, colleges or research institutions according to the needs of the industry and common interests, giving full play to their respective advantages, and promoting each other among the main bodies in the mode. The innovation of scientific research and the innovation of vocational education enrich the development mode of enterprises. In this mode, the enterprises provide the first mock exam points and equipment to the cooperative institutions according to the analysis of market demand, and the institutes will put the research results in various stages into the enterprises for examination. The first mock exam has achieved the win-win results of enterprise interests, market demand and research efficiency, and achieved the goal of promoting education development with industry demand. But only in view of cost and demand, only some high tech enterprises and universities with strong scientific research ability have carried out this type of cooperation.

Case: a renewable resources Co., Ltd. and a vocational college carry out industry university research cooperation. The enterprise is a Sino foreign joint venture state-level high-tech enterprise, specializing in water resources utilization, river regulation and water environment protection, etc. according to the demand of technology and market development, the enterprise carries out industry university research cooperation with the college. The University sends professional professors into the enterprise from time to time to help the enterprise with advanced technology to upgrade technology and jointly develop environmental protection Automatic terminal equipment and put into use.

\section{Acknowledgements}

Based on Jilin occupation education and adult education reform research topics: Research on the dynamic mechanism of occupation poverty alleviation in Jilin province with new apprenticeship as the path (2019ZCY331).

\section{References}

1 Lili. Private enterprise undergraduate school enterprise cooperation, production and teaching integration personnel training mode to explore [J]. Think Tank Era, 2017 (01).

$2 \mathrm{Xu}$ Meiling, Wang Yunli. Research on the innovation of compound talents training mode from the perspective of "school enterprise cooperation and industry education integration" [J]. Modern Economic Information, 2019 (10). 